\title{
Pienet asunnot Vantaalla
}

\section{Elisa Ranta}

Vantaa kasvaa tällä hetkellä vauhdikkaammin kuin vuosikymmeniin. Asuntotuotanto ylitti vuonna 2018 kaikki aikaisempien vuosikymmenten ennätykset 4500 asunnon rakentamisvauhdilla. Samaan aikaan kaupunkiin muutti yli 5100 uutta vantaalaista, mikä on enemmän kuin yhteenkään muuhun Suomen kaupunkiin. Vantaa on väestömäärään suhteutettuna myös Suomen monikulttuurisin kaupunki lähes 19 prosentin vieraskielisen väestön osuudella.

Vantaan viime vuosien vilkasta kasvua on siivittänyt yhä voimistuva kaupungistuminen ja pääkaupunkiseudun kasvava vetovoima. Asuntorakentamisen mahdollisuuksia joukkoliikenteen yhteyteen on lisännyt etenkin vuonna 2015 avautunut Kehärata. Viimeisen viiden vuoden aikana kilometrin säteellä junaasemista on valmistunut Vantaalle yli 10 ooo asuntoa. Uusi rakentaminen syntyy siis Vantaalla pitkälti erittäin hyvien joukkoliikenneyhteyksien läheisyyteen.

Samalla kun asuntojen määrä on vuosi vuodelta kasvanut, niiden keskikoko on jatkuvasti pienentynyt. Kun vuonna 2006 Vantaalle uusiin kerrostaloihin valmistuvien yksiöiden keskipinta-ala oli 41,8 neliötä, vuonna 2018 kaikkien uusien kerrostaloasuntojen keskipinta-ala oli 44,4 neliötä. Kerrostaloihin valmistuneiden yksiöiden keskikoko vuonna 2018 oli 30,3 neliötä. Valmistuvien asuntojen huoneistotyypit painottuvat myös yhä useammin pieniin asuntoihin. Vuonna 2018 uusista kerrostaloasunnoista 37 prosenttia oli yksiöitä ja 39 prosenttia kaksioita. Yli neljän makuuhuoneen perheasuntojen osuus kerrostaloasunnoista oli vain kolme prosenttia. Huomattavasti keskikooltaan pienentynyt asuntojen uudistuotanto ei ole vielä vaikuttanut suuressa mittakaavassa kaupungin koko asuntokannan keskikokoon.

\section{Pienten asuntojen buumi}

Uusien asuntojen keskikoon pienentyminen ja yksiöiden tarjonnan lisääntyminen markkinoilla on tapahtunut Vantaalla sekä muissa Suomen suurissa 
kaupungeissa varsin nopeasti. Vantaalla asuntorakentaminen painottuu myös yhä vahvemmin kerrostaloihin, joihin valmistuu jo lähes 90 prosenttia uusista asunnoista.

Pienten asuntojen rakentumista viime vuosina on vauhdittanut kasvanut kiinnostus asuntosijoittamiseen niin yksityisten kuin institutionaalisten sijoittajien toimesta. Kasvukeskusten asuntomarkkinoilta on viime vuosina saanut parempia tuottoja sijoitetuille pääomille moniin muihin sijoituskohteisiin verrattuna. Asuntosijoittajien kohteena ovat olleet nimenomaan yksiöt tai kaksiot, joille on ollut kysyntää markkinoilla jatkuvan kaupungistumisen ja pienten kotitalouksien määrän kasvun myötä. Verottaja kohtelee edullisesti sijoitusasuntojen omistajia, joille verotettavaksi pääomatuloksi katsotaan vain se tuotto, joka jää asunnosta koituvien kulujen, kuten asunnon hoitovastikkeen ja tietyin edellytyksin myös rahoitusvastikkeen jälkeen. Rakennusliikkeiden asuntokohteiden myyntiä ja rakenteille lähtöä on vauhdittanut se, että sijoittajat ovat usein varanneet ison osan talon pienistä asunnoista jo ennakkovarausvaiheessa.

Vantaan kaupunki on edellyttänyt uusilla asuinalueilla pidemmän aikaa asuntojen hallintamuotojen monipuolisuutta, mutta menneinä vuosina ei ole säädelty asuntojen huoneistotyyppejä tai keskipinta-alaa. Pienten asuntojen rakentumista kaupunkiin on edesauttanut kevennetyn pysäköintinormin kokeilu määriteltyjen keskusta-alueiden uusissa asuinrakennuskohteissa vuosina 2011-2018. Kokeilun myötä asuntokohtaisia pysäköintipaikkoja ei ole tarvinnut enää rakentaa ja kokeilualueilla mitoituksena on ollut 1 autopaikka 130 kerrosneliömetriä kohden. Pysäköintipaikkojen kevennyksen myötä keskusta-alueiden rakentaminen on saatu tiiviimmäksi ja täydennysrakentamiskohteita on ollut paikoittain helpompi toteuttaa. Joiltakin alueilta, joissa on käytetty kevennettyä normia, on saatu asukkailta kritiikkiä pysäköintipaikkojen vähäisestä määrästä.

Keskikooltaan pieniä asuinkohteita on rakentunut Vantaalla erityisesti uusille kerrostaloalueille, kuten Kivistöön ja Leinelään sekä keskuksiin, kuten Tikkurilaan ja Myyrmäkeen. Vantaalla on toteutettu myös paljon julkisuutta saanut Saton Studiokotihanke, jossa sallittiin 15,5-neliöisten asuntojen kokeiluluontoinen rakentaminen. Huoneistojen koossa rakentamismääräyskokoelmasta annettiin poikkeus sillä ehdolla, että toteuttaja tekee hankkeesta viiden vuoden seurantatutkimuksen yhteistyössä kaupungin kanssa. Ensimmäisten selvitysten mukaan kohteen asukastyytyväisyys on erittäin korkealla tasolla.

Pienten asuntojen buumin ohella vapaarahoitteisten vuokra-asuntojen osuus asuntotuotannosta on kasvanut liki 30 prosentin osuuteen vuosittaisesta asuntotuotantomäärästä. Institutionaaliset sijoittajat ja vuokrataloyhtiöt rakennuttavat kokonaisia vuokrataloja, mutta myös omistusasuntotuotantoon 
valmistuvasta asuntokannasta osa, etenkin pienet asunnot, menevät sijoittajille. Vantaalla on arvioitu, että uusista omistusasunnoiksi rakennetuista kerrostaloasunnoista noin 30 prosenttia päätyy sijoittajien vuokra-asunnoiksi. Mikäli osakkeenomistajista vain osa asuu itse rakennuksessa tai sijoittajataho omistaa ison osan yhtiön asunnoista, taloyhtiön päätöksenteko saattaa muodostua haastavaksi. Riskinä myös on, että pitkälti taloyhtiöiden lainoihin nojaavat sijoitusasuntokohteet jäävätkin mahdollisten vuokratappioiden ja omistajatahon taloudellisten vaikeuksien myötä asunto-osakeyhtiön maksettavaksi.

\section{Uhka vai mahdollisuus?}

Vantaalla herättiin toden teolla asuntojen jatkuvaan pienenemiskehitykseen ja yksiö- sekä kaksiovaltaisten talojen rakentumiseen vuonna 2016. Asiaa päätettiin tutkia tarkemmin tilastojen valossa, mutta myös selvittää asukasnäkökulmaa uusissa kerrostaloissa asuvilta vantaalaisilta. Keväällä 2017 lähetettiin asukaskysely lähes 2000 kotitalouteen, jotka asuivat uusissa kerrostaloissa, joiden asuntojen keskipinta-ala oli alle 50 huoneistoneliötä. Kyselyllä haluttiin saada tietoa myös yleisesti tyytyväisyydestä asumiseen ja asuinympäristöihin, sillä samaan aikaan valmisteltiin Vantaan uusia maa- ja asuntopoliittisia linjauksia.

Tehdystä kyselystä selvisi, että uusien kerrostalojen yksiöissä asuu runsaasti nuoria, alle 30-vuotiaita asukkaita. Vastaajat olivat keskimäärin tyytyväisiä asumiseensa niin asunnon kuin asuinalueen osalta ja asuntojen koettiin sopivan nykyiseen elämäntilanteeseen hyvin. Tulevaisuudessa asunnonvaihtoa pidettiin kuitenkin todennäköisenä: yli puolet vastaajista suunnitteli muuttoa pois viiden vuoden sisällä. Asumistoiveissa oli siirtyminen isompaan asuntoon ja halu vaihtaa asunnon hallintamuotoa omistusasumiseen. Tutkimuksen otoksen pienten asuntojen sijainti katsottiin vastaajien mielestä hyväksi niin joukkoliikenneyhteyksien, palveluiden kuin luonnonläheisyydenkin osalta. (Virtanen 2017, 5-7, 22-23, 25.)

Pienille asunnoille on riittänyt markkinoilla kysyntää, mutta tulevaisuuden uhkakuvana saattaa olla se, että yksiö-ja kaksiovaltaisista taloista muodostuu vain lyhyen aikavälin asumistarpeita ratkaisevia kohteita. Ongelmana on, että uusilla kerrostalovaltaisilla asuinalueilla isompia, esimerkiksi perheille suunnattuja asuntoja on vähän tarjolla. Tämä johtaa siihen, että elämäntilanteen muuttuessa, esimerkiksi parisuhteen tai perheen perustamisen myötä, ihmiset muuttavat pois alueelta. Tilastollisesti trendiä on vielä vaikea osoittaa, sillä uusilta kerrostaloalueilta ei ole vielä olemassa pidemmän ajan muuttodataa. Muuttoliike Vantaalla 2008-2017-tutkimuksessa on nähtävissä viitteitä, että uusien kerrostaloalueiden pienissä asunnoissa asutaan lyhyemmän aikaa kuin vastaavissa muiden alueiden yksiöissä tai kaksioissa. Uusilta kerrostalovaltai- 
silta asuinalueilta lapsiperheet muuttavat pois hieman enemmän kuin muilta asuinalueilta. (Ala-Mantila 2019, 20-21.)

Kaupungin kannalta alueet, joissa muuttoliike on vilkasta, saattavat muodostua haasteellisiksi. Lyhyen aikaa alueilla asuvat asukkaat eivät juurru ympäristöönsä yhtä todennäköisesti kuin pidemmän aikaa asuvat. Yksipuolisista asumisen vaihtoehdoista aiheutunut muuttoliike voi tuoda mukanaan alueelle levottomuutta, välinpitämättömyyttä asuinympäristöstä ja aikanaan negatiivista eriytymiskehitystä. Vantaan asukaskyselystä syvennetty pro gradu -tutkielma osoitti, että yksiöiden runsas määrä asuinrakennuksessa on yhteydessä muuttoaikeisiin sekä turvattomuuden kokemuksiin: kun yksiöiden määrä ylitti rakennuksen koko huoneistotyyppijakaumasta 30 prosenttia, lisääntyivät sekä muuttoaikeet että turvattomuuden kokemukset merkittävästi. Asuinaluetasolla vastaavaa ilmiötä ei ole havaittavissa. (Virtanen 2018, 48.)

Pienet asunnot, joissa vuokra on vielä maksettavissa olevan suuruinen, mahdollistavat monille muuttajille asuinpaikan Vantaalla. Näistä tulomuuttajista voi vuosien varrella kasvaa kaupungille pysyviä kuntalaisia. Tästä syystä on tärkeää, että "sisäänheittotuotteina" toimivien pienten asuntojen rinnalle löytyy Vantaan asuntomarkkinoilta myös kohtuullisen kokoisia ja erilaisten ihmisten maksukyvylle sopivia koteja, joissa on mahdollista jatkaa vantaalaista asumisuraa.

\section{Kohti monipuolisempaa uudisrakentamista}

Vuonna 2018 Vantaalla hyväksyttiin uudet maa- ja asuntopoliittiset linjaukset, joissa annettiin poliittinen selkänoja kirjata huoneistotyyppi-sekä hallintamuototavoitteet maankäyttösopimuksiin sekä tarpeen vaatiessa huoneistotyypit myös asemakaavoihin. Tätä päätöstä alettiin soveltaa uusien kaavahankkeiden yhteydessä niin, että asuinrakennusten asunnoista korkeintaan 30 prosenttia saa olla yksiöitä. Vuoden 2019 alkupuolelta lähtien yksiöiden määrän rajoittamisen lisäksi on edellytetty kolmioiden ja sitä suurempien asuntojen osuuden olevan rakennuksissa vähintään 30 prosenttia.

Asuntovalikoiman monipuolisuutta on edellytetty jo pidempään hallintamuotojen osalta. Uusilla kaavoitettavilla alueilla varmistetaan MAL-sopimuksen mukaisten tavoitteiden toteutuminen eli asuntotuotannosta puolen edellytetään olevan omistusasumista ja kolmasosan valtion tukemaa tuotantoa, josta 20 prosenttia pitkän korkotuen vuokra-asuntoja ja kymmenen prosenttia esimerkiksi lyhyen korkotuen vuokra-asuntoja tai asumisoikeustuotantoa. Huoneistotyyppi- ja hallintamuototavoitteet kirjataan yksityisen maalle kaavoitettaessa maankäyttösopimuksiin ja ne sanktioidaan sopimussakkoehdoin. Vantaan itse omistaman maan kilpailutuksissa ja luovutuksissa asuntopoliittiset 
tavoitteet voivat olla vielä tiukempia. Huoneistotyyppi-ja hallintamuotoehdot tarkastellaan aina tapauskohtaisesti ja esimerkiksi erityisryhmien asuntokohteissa yksiöitä voi olla enemmän.

Kaupungin käymät keskustelut rakennuttajien kanssa huoneistotyyppien säätelystä ovat sujuneet pääosin hyvin. Ymmärrystä monipuolisen asuntojakauman tarpeeseen löytyy myös neuvottelupöydän toiselta puolelta. Vaikka kaksiot tai sitä useamman huoneen asunnot voivat olla neliömäärältään melko pieniä, on Vantaalla katsottu, että ne ovat asukkailleen eri elämäntilanteissa joustavampi vaihtoehto kuin yksiöt.

Kaupunki toteuttaa kahden vuoden välein asukasbarometrin, jossa selvitetään asukkaiden tyytyväisyyttä omaan asuinympäristöön ja -alueeseen. Ensimmäisestä, keväällä 2019 valmistuneesta barometrista saatiin tietoa, että vantaalaiset ovat keskimäärin tyytyväisiä niin asuntoonsa kuin asuinalueeseensa. Asukasbarometrin toivotaan tulevaisuudessa antavan tietoa myös huoneistotyyppien vaikutuksesta asumisviihtyvyyteen.

Pienten asuntojen suuresta kysynnästä huolimatta kaupungin on katsottava asuntopolitiikkaa pitkällä tähtäimellä, koska asuintalot rakennetaan seuraavaksi 50-100 vuodeksi. Se, että tuotetaan suuret määrät juuri nykyiseen markkinatilanteeseen vastaavaa yksipuolista asuntotuotantoa, saattaa osoittautua tulevaisuudessa virheeksi, jonka velkoja maksetaan eriytymiskehityksenä tai epäkuranttien asuinrakennusten ennenaikaisena purkamisena. Edelleen kaivataan lisää tutkittua tietoa pienten asuntojen hyvistä ja huonoista puolista sekä niiden vaikutuksesta asuinalueisiin. Tulevaisuuden asumistarpeita on hyvin vaikea ennustaa, mutta paras keino varautua erilaisiin kehityssuuntiin on varmistaa asuntotuotannon monipuolisuus niin huoneisto-, hallintamuotokuin talotyypin osalta.

Kirjoittaja työskentelee asumisen erityisasiantuntijana Vantaan kaupungilla.

KIRJALLISUUS

Ala-Mantila, Sanna (2019). Muuttoliike Vantaalla 2008-2017 - Ketkä tulevat, ketkä lähtevät? Vantaan kaupunki. Tietopalvelu C1: 2019. [viitattu 7.5.2019] <https://www.vantaa.fi/instancedata/prime_ product_julkaisu/vantaa/embeds/vantaawwwstructure/142920_Muuttoliike_Vantaalla_2008-2017. pdf>

Virtanen, Elina (2017). Asumiskokemuksia uusista vantaalaisista kerrostaloasunnoista ja -alueista. Vantaan kaupunki. Kiinteistöt ja asuminen. [viitattu 7.5.2019] <https://www.vantaa.fi/instancedata/prime_ product_julkaisu/vantaa/embeds/vantaawwwstructure/134810_Asumiskokemuksia_280917.pdf >

Virtanen, Elina (2018). Uusissa vantaalaisissa kerrostaloissa asuvien muuttoaikeet ja niihin vaikuttavat tekijät. Pro Gradu -tutkielma, Helsingin yliopisto. 